\title{
MANAJEMEN PEMBELAJARAN BERBASIS SEKOLAH ALAM DALAM MEMBENTUK KARAKTER PESERTA DIDIK
}

\section{SCHOOL-BASED LEARNING MANAGEMENT OF NATURE IN SHAPING THE CHARACTER OF LEARNERS}

\author{
SL Izzati1a dan E Anwar ${ }^{1}$ \\ ${ }^{1}$ Program Studi Manajemen Pendidikan Islam, Fakultas Keguruan dan Ilmu Pendidikan, \\ Universitas Djuanda Bogor, Jl. Tol Ciawi No. 1 Kotak Pos 35 Ciawi Bogor 16720 \\ a Korespondensi: Sity Laili Izzati, Email: lailiizzati2@gmail.com \\ (Diterima: 12-02-2017; Ditelaah: 14-02-2017; Disetujui: 17-04-2017)
}

\begin{abstract}
This study aims to determine the planning, organizing, implementation, supervision, and evaluation of nature school-based learning in shaping the character of students in Ibnu Hajar Islamic Elementary School Bogor. To achieve these objectives, this research used qualitative descriptive study to examine the condition of natural objects. Data were collected using: interview, observation, and documentation. Data analysis used: data collection, data reduction, display / data presentation, and verification. Validity check of data using: credibility, flexibility, dependency, and certainty. The results showed: (1) learning management based on nature schools in Ibnu Hajar Islamic Elementary School Bogor conducted with the initial activity, ie preparing the lesson plan at the beginning of each semester and learning program planning that combines the curriculum diknas and curriculum typical of the school into three contents namely ma'rifatullah, ma'rifatul insan, ma'rifatul alam. At the organizing stage, a team responsible for the planning of learning and division of the task of making RPP in each level of different classes. Learning implementation in this school using the approach of scientific learning, thematic learning method, and learning strategies that conceptualize STIFIn learning. Monitoring stage of learning that is principal doing examination of RPP, observation of learning activity, and reporting of program development; and (2) the values of the characters developed in the course of the Ibnu Hajar school are applied in every activity with the establishment of values, leadership, and entrepreneurial spirit.
\end{abstract}

Keywords: characters student, learning management, nature schools.

\begin{abstract}
ABSTRAK
Penelitian ini bertujuan untuk mengetahui perencanaan, pengorganisasian, pelaksanaan, pengawasan, dan evaluasi pembelajaran berbasis sekolah alam dalam membentuk karakter peserta didik di SDIslam Ibnu Hajar Bogor. Untuk mencapai tujuan tersebut, metode kualitatif penelitian ini merupakan jenis penelitian deskriptif yang berlandaskan filsafat pospositivisme. Teknik pengumpulan data dilakukan dengan menggunakan: wawancara, observasi, dan dokumentasi. Analisis data menggunakan: pengumpulan data, reduksi data, display/penyajian data, dan verifikasi. Pengecekan keabsahan data menggunakan: derajat kepercayaan, keteralihan, kebergantungan, dan kepastian. Hasil penelitian ini menunjukkan: (1) manajemen pembelajaran berbasis sekolah alam di SD Islam Ibnu Hajar Bogor dilakukan dengan kegiatan awal yaitu menyiapkan lesson plan setiap awal semester dan perencanaan program pembelajaran yang memadukan kurikulum dinas dan kurikulum khas SDIslam Ibnu Hajar menjadi tiga muatan yaitu ma'rifatullah, ma'rifatul insan, ma'rifatul alam. Pada tahap
\end{abstract}


pengorganisasian dibentuk tim penanggung jawab perencanaan pembelajaran dan pembagian tugas pembuatan RPP di setiap level kelas yang berbeda. Pelaksanaan pembelajaran di SDIslam Ibnu Hajar menggunakan pendekatan pembelajaran saintifik, metode pembelajaran tematik, dan strategi pembelajaran yang berkonsepkan STIFIn learning. Tahap pengawasan pembelajaran yaitu kepala sekolah melakukan pemeriksaan RPP, pengamatan kegiatan pembelajaran, dan pelaporanperkembangan program; dan (2) nilainilai karakter yang dikembangkan dalam pembelajaran di SD Islam Ibnu Hajar diterapkan di setiap aktivitas dengan pembentukan nilai-nilai, jiwa kepemimpinan, dan jiwa kewirausahaan. Kata kunci: karakter peserta didik, manajemen pembelajaran, sekolah alam.

Izzati SL, RSP Fauziah, dan A Kholik. 2017. Manajemen pembelajaran berbasis sekolah alam dalam membentuk karakter peserta didik. Tadbir Muwahhid 1(1): 57-70.

\section{PENDAHULUAN}

Pendidikan merupakan cerminan kebudayaan bagi manusia yang dinamis dan penuh dengan perkembangan. Adanya perkembangan dalam dunia pendidikan merupakan hal yang ditunggu seiring dengan kemajuan zaman. Oleh karena itu, pendidikan membutuhkan perbaikan untuk meningkatkan mutu pendidikan yaitu sejalan dengan tuntutan masyarakat modern yang selalu ingin adanya perubahan yang baik (improvement oriented).

Dalam ruang lingkup pendidikan, manajemen pembelajaran menduduki peranan yang sangat penting. Karena, pada intinya manajemen pembelajaran ialah pengelolaan seluruh kegiatan pembelajaran mulai dari proses perencanaan, pengorganisasian, pelaksanaan, pengawasan, dan evaluasi pembelajaran yang efektif dan efisien agar dapat mencapai tujuan pembelajaran. Dengan adanya manajemen pembelajaran yang tersistem otomatis akan meningkatkan kualitas pembelajaran yang dapat lebih mengeksplorasi bakat peserta didik sesuai kemampuan masing-masing.

Fokus kegiatan pembelajaran yaitu adanya hubungan sosial pendidik yang mempengaruhi peserta didik pada materi pelajaran yang telah tersusun dalam kurikulum yang telah ditetapkan. Dalam menguasai bahan dan materi ajar pada kegiatan pembelajaran para pendidik perlu mengetahui cara penyampaian materi ajar pada pserta didik dan mengetahui karakteristik peserta didik yang menerima materi pelajaran tersebut (Sagala 2013).

Mengingat realita kemerosotan akhlak sudah sedemikian memburuk, pendidikan sekolah selama ini tidak berhasil dalam segi karakter. Sekolah melupakan pendidikan karakter karena terlalu tertarik dengan target-target akademis saja. Realitas yang kini dirasakan membuat anak mudah frustasi, kehilangan semangat juang, dan menyerah, yang akan berdampak pada rendahnya ketahanan pada ujian hidup, kemandirian, kreatifitas, dan keberanian menghadapi resiko (Ma'mun 2012).

Dalam UU No. 20 Tahun 2003 tentang Sispennas pasal 3, yang menyebutkan bahwa ada dua fungsi pendidikan nasional. Fungsi pertama, "mengambangkan kemampuan" dapat dipahami bahwa pendidikan nasional menganut aliran kontruktivisme, yang mempercayai bahwa peserta didik dapat berkembang menjadi manusia yang berpotensi seoptimal mungkin melalui proses pendidikan. Fungsi kedua "membentuk karakter" memiliki arti bahwa pendidikan nasional harus ditujukan pada pembentukan karakter. Pendidikan yang 
bermaksud pada karakter peserta didik sebagai suatu hal yang tepat, tetapi penting untuk diklarifikasi mengenai istilah perlakuan terhadap "karakter". Apakah karakter itu seharusnya dikembangkan atau difasilitasi. Perspektif pedagogik memandang dan mensyaratkan peserta didik bukanlah sebagai objek didik tetapi sebagai subjek didik adanya kebebasan dalam proses pendidikan (Kesuma et al. 2013).

Belum maksimalnya penyelenggaraan di Indonesia dalam sistem pendidikan memicu munculnya sekola-sekolah alternatif yang diyakini lebih memiliki mutu yang lebih baik daripada sekolah-sekolah seperti biasa. Salah satu bentuk sistem pendidikan yng saat ini mulai berkembang di Indonesia adalah pendidikan Sekolah Alam. Sistem pendidikan sekolah ini berbeda dari sekolah formal umumnya.

Sekolah alam menciptakan pembelajaran dengan suasana lebih cair, segar, dan penuh kesenangan yang tentunya akan menarik peserta didik untuk terus mencari dan menemukan sesuatu. Sekolah alam menerapkan model pembelajaran berdasarkan pengalaman peserta didik yang lebih menghargai proses pencarian dan penemuan (Santyas 2008)

Salah satu sekolah alam yang kini mulai berkembang di daerah Bogor yaitu SD Islam Ibnu Hajar Bogor yang bergabung dalam Jaringan Sekolah Alam Nusantara yang hadir bersama dengan ragam model pendidikan alternatif yang saat ini berkembang. Untuk memunculkan model pendidikan yang berbeda dengan sekolah konvensional. SD Islam Ibnu Hajar adalah sebuah lembaga model pendidikan yang berusaha mengadaptasikan apa yang telah dibuktikan oleh Rasulullan Saw pada masanya ke masa sekarang dan masa generasi rabbani nanti yang akan memimpin di muka bumi.
SD Islam Ibnu Hajar Bogor menawarkan model pembelajaran yang mempunyai keunikan dan menyenangkan, yang mengutamakan karakter, berpusat pada anak dengan metode pembelajaran yang mengoptimalkan potensi lokal dan alam sekitar sebagai sumber belajar. SD Islam Ibnu Hajar memandang bahwa sekolah tidak cukup untuk membuat peserta didik pandai, tetapi sekolah harus dapat menganalisis dan mengelola potensi genetik yang berbasis mesin kecerdasan STIFIN. SD Islam Ibnu Hajar menerapkan model penempaan bakat dan minat peserta didik sejak dini, dikarenakan bakat dan minat yang dimiliki setiap peserta didik berbeda-beda mengingat bahwa masalah yang timbul semakin kompleks dan harus dipersiapkan dengan kemampuan yang dimiliki peserta didik harus kuat.

\section{MATERI DAN METODE}

\section{Materi}

\section{Manajemen Pembelajaran Sekolah Alam}

Menurut George R. Terry menyebutkan bahwa manajemen merupakan suatu kerangka kerja yang membutuhkan pengarahan dan bimbingan suatu kelompok untuk mencapai tujuan organisasi yang nyata (Bafadal 2012). Manajemen adalah suatu aktivitas dan proses mengelola sumber daya manusia serta sumber lainnya untuk mencapai tujuan organisasi yang telah ditetapkan.

Berkaitan dengan pengertian pembelajaran, pembelajaran adalah salah satu sistem pendidikan yang harus dikelola dengan baik. Adapun dalam pengertian pembelajaran yaitu sub sistem pendidikan, di samping kurikulum, administrasi, konseling, dan evaluasi (Yamin 2013). Secara 
sederhana, istilah pembelajaran (instruction) bermakna untuk membelajarkan seseorang atau kelompok orang melalui berbagai upaya (effort) dan berbagai pendekatan, metode, dan strategi dalam mencapai tujuan (Majid 2013).

Menurut Miarso pembelajaran yaitu suatu usaha yang bertujuan, terkendali, dan disengaja agar orang lain belajar sehingga terjadi perubahan yang relatif menetap pada diri orang lain. Usaha tersebut dapat dilakukan oleh seorang atau kelompok orang yang memiliki kemampuan atau kompetensi dalam merancang atau mengembangkan sumber belajar yang diperlukan (Yamin 2013).

Dengan demikian, pengertian pembelajaran adalah suatu kegiatan yang direncanakan dan dirancanguntuk mempelajari suatu kemampuan atau nilai yang baru yang melibatkan komponenkomponen dalam pembelajaran yang menyesuaikan karakter peserta didik dalam mencapai tujuan pembelajaran.

Fungsi manajemen di antaranya adalah sebagai berikut.

1. Penerapan Perencanaan

Proses perencanaan dilaksanakan secara kolaboratif atau kerjasama, artinya dengan mengikut sertakan personel sekolah dalam semua tahap perencanaan. Hoyle berpendapat bahwa sangat perlu bagi masyarakat sekolah, semua pengajar dan personel lain yang berkepentingan dengan tujuan sekolah harus dapat bertanggung jawab dan dilibatkan dalam perencanaan yang telah ditetapkan. Perencanaan pembelajaran memandu guru sebagai pendidik dalam melayani kebutuhan belajar peserta didiknya dan melaksanakan tugas profesionalnya (Sagala 2013). Dalam perencanaan proses pembelajaran memiliki 2 aspek yaitu silabus dan RPP berkomponen identitas mata pelajaran, standar kompetensi, kompetensi dasar, indikator pncapaiaan, tujuan pembelajaran, materi ajar, alokasi waktu, pendekatan dan metode pembelajaran, sumber belajar, serta penilaian hasi belajar (Majid 2012).

2. Penerapan Pengorganisasian

Kegiatan pengorganisasian pembelajaran bagi tiap guru dalam institusi sekolah dimaksudkan untuk menentukan siapa yang akan bertugas sesuai dengan prinsip pengorganisasian, bidang, wewenang, mata pelajaran, dan tanggung jawabnya dan membagi tanggung jawab setiap personel sekolah dengan jelas dilihat dari komponen yang terkait dengan pembalajaran pada institusi sekolah. Gorton berpendapat bahwa pengorganisasian yaitu membagi habis dan menstrukturkan tugas-tugas ke dalam sub-sub atau komponenkomponen organisasi terbaginya tugas ke dalam yang efektif (Sagala 2013).

3. Penerapan Pelaksanaan Pembelajaran

Terry mengemukakan bahwa pelaksanaan (actuating) mengandung arti kemampuan untuk melaksanakan tugas-tugas dengan antusias yang baik dan dapat merangsang anggota kelompok agar tercapainya tujuan organisasi (Sagala 2013). Pelaksanaan pembelajaran merupakan penerapan dari rencana pelaksanaan pembelajaran yang telah dirancang sebelumnya, meliputi beberapa hal sebagai berikut.

a. Kegiatan Pendahuluan

Dalam kegiatan pendahuluan guru mempersiapkan peserta didik secara fisik maupun psikisnya agar dapat mengikuti proses pembelajaran, mengajukan kuesioner yang 
mengintegrasikan materi terdahulu dengan materi yang akan dipelajari, menerangkan kompetensi dasar dan tujuan pembelajaran yang akan dicapai, dan menjelaskan materi dan menyampaikan uraian kegiatan sesuai silabus (Majid 2012).

b. Kegiatan Inti

Kegiatan inti merupakan penyampaian materi dengan menggunakan berbagai metode pengajaran yang sesuai dengan karakteristik dan mata pelajaran, inti pembelajaran meliputi proses eksporasi, elaborasi, dan konfirmasi.

c. Kegiatan Penutup

Dalam kegiatan ini guru dan peserta didik membuat rangkuman atau kesimpulan pelajaran bersama-sama, melakukan refleksi dan penilaian setelah selesai melaksanakan kegiatan secara konsisten dan terprogram, memberikan stimulus respon terhadap proses dan hasil pembelajaran, merencanakan tindak lanjut dalam konseling dan sesuai dengan pencapaian peserta didik, serta menyampaikan rencana kegiatan pembelajaran pada pertemuan berikutnya (Majid 2012).

4. Penerapan Pengawasan

Anthony et al. dalam Sagala (2013) mengemukakan bahwa pengawasan dimaksudkan untuk memastikan supaya anggota dapat mengendalikan organisasi melalui upaya menganalisis, mengumpulkan, melaksanakan apa yang dikehendaki, dan mengevaluasi informasi serta memanfaatkannya. Dalam tahap ini, kepala sekolah melakukan pengawasan terhadap seluruh kelas apakah terjadi kegiatan belajar mengajar. Jadi pengawasan dapat dipandang dari segi input, proses, dan output bahkan outcome. Adapun guru melakukan pengawasan terhadap program yang telah ditentukan sebelumnya, apakah sudah dilaksanakan sesuai rencana atau tidak. Jika ada kekeliruan atau ada program yang bermasalah dan tidak dapat terselesaikan dengan baik segera dilakukan perbaikan dalam perencanaannya sehingga tujuan yang sebelumnya ditentukan tetap secara maksimal dapat dipenuhi dan tercapai. Pengawasan dalam perencanaan pembelajaran, meliputi: (a) mengevaluasi pelaksanaan kegiatan, dibanding dengan rencana, (b) merumuskan tindakan koreksi, menyusun standardisasi dan sasaran pembelajaran, dan (c) melakukan pengkoreksian terhadap penyimpanganpenyimpangan baik dalam proses pembelajaran maupun satuan pendidikan.

5. Penerapan Fungsi Evaluasi

Evaluasi dalam pembelajaran merupakan penetapan nilai sehubungan dengan fenomena pendidikan. Kegiatan evaluasi yang dilaksanakan oleh pendidik akan terlihat sejauh mana keberhasilan pembelajaran peserta didiknya (Arikunto 2002). Evaluasi secara spesifik yang berkaitan dengan evaluasi hasil pembelajaran adalah keseluruhan kegiatan pengukuran, pertimbangan untuk membuat keputusan, pengolahan, dan penafsiran tentang hasil belajar dalam upaya mencapai tujuan pembelajaran yang telah ditetapkan. (Hamalik 2001). Tujuan evaluasi bagi pendidik yaitu mengetahui keberhasilan penguasaan peserta didik terhadap pelajaran, ketepatan atau efektivitas metode mengajar (Arikunto 2002). 
Sekolah alam menerapkan konsep pendidikan yang memanfaatkan alam sebagai sarana belajar bukan berupa gedung bertingkat dan megah sebagai ruang kelas seperti sekolah umum, melainkan rumah panggung (disebut juga saung) yang dikelilingi oleh berbagai kebun bunga,sayur, buah, atau area peternakan sehingga proses pembelajaran yang berlangsung di sekolah alam dalam suasana fun learning tanpa ada tekanan dan jauh dari kebosanan. Hal itu sangat membantu anak-anak menikmati masa-masa awal pertumbuhan dan perkembangannya sehingga dapat membangun imajinasi-imajinasi positif tentang kehidupan nyata yang mereka alami sendiri (Maryati 2007).

\section{Pengelolaan Sekolah Alam}

Menurut Muhaimin et al. (2011), beberapa aspek yang harus menjadi perhatian kepala sekolah untuk dirancang dengan cermat dan benar apabila mengelola sekolah alam yaitu sebagai berikut.

a. Pengembangan Kebijakan Sekolah

Kebijakan sekolah alam harus tersirat kepedulian terhadap alam dan berbudaya terhadap lingkungan alam. Pengembangan kebijakan tersebut antara lain: 1) kurikulum yang dipakai berbasis sekolah alam, 2) kegiatan pembelajaran, 3) visi dan misi harus memuat konsep sekolah alam, 4) mendukung terciptanya lingkungan sekolah yang bersih dan sehat, dan 5) pengalokasian dan penggunaan dana untuk kegiatan yang terkait dengan pembelajaran berbasis alam (Muhaimin et al. 2011).

b. Program Sekolah Alam

Program kerja perlu dirumuskan dengan jelas, baik dalam jangka panjang, menengah, maupun dalam jangka pendek. Jangka panjang dapat dirumuskan dalam rencana strategik, yang mencakup: visi, misi, tujuan, kebijakan, strategi, dan program untuk kurun waktu 5-10 tahun. Jangka menengah meliputi strategi dan program yang akan direalisasikan dalam waktu 3-5 tahun. Jangka pendek meliputi program yang disusun dan direalisasikan setiap tahun ajaran. (Mulyasa 2011).

Kokom (2010), juga berpendapat bahwa program sekolah alam juga harus mampu menciptakan kegiatan pembelajaran di bidang lingkungan alam berbasis partisipatif di sekolah seperti: berkebun, berternak, outbond, camping, outing, market day, dll. Kegiatan pembelajaran di sekolah alam dikembangkan berdasarkan pendekatan kontekstual yang berkaitan dengan lingkungan fisik. Lingkungan fisik, berkenaan dengan aspek alamiah muka bumi seperti SDM (air, hutan, tanah, udara, matahari, batuan), flora, fauna, sungai, limbah, iklim, termasuk pula pelestarian lingkungan yang ada di sekitar kehidupan peserta didik.

2. Keunggulan Sekolah Alam

Sekolah alam memiliki keunggulan dibandingkan dengan sekolah umum lainnya. Adapun keunggulan sekolah alam, yaitu. Pertama, konsep sekolah alam yang mengintegrasikan kurikulum dinas dan kurikulum sekolah alam menjadi tiga pilar pendidikan yang menjadi faktor kunci keunggulan umat manusia, yaitu pilar iman, ilmu, dan kepemimpinan.

Kedua, model pembelajaran sekolah alam mengimplementasikan materi ajar dengan alam dan potensi lokal. Untuk mewujudkan maksud tersebut, sekolah 
alam melakukan berbagai upaya yaitu pengembangan metode pembelajaran yang efektif, peningkatan kualitas guru, serta penyediaan sumber dan media belajar yang memadai.

Ketiga, dalam menerapkan ilmu pengetahuan, metode spider-web sangat cocok diterapkan di sekolah alam ini, sumber belajar menggunakan alam dan media belajar dengan diajarkan bagaimana berbisnis. Guru berperan sebagai fasilitator bagi peserta didik untuk berinteraksi dengan alam dengan rangkaian tema/projek pembelajaran tertentu sehingga anak mendapatkan pemahaman yang holistik mengenai alam semesta.

Keempat, dalam membentuk karakter peserta didik sekolah alam melatih jiwa kepemimpinan peserta didik dengan menggunakan metode outbound. Guru melakukan aktivitas outbond secara praktis bersama peserta didik. Dalam melatih pembentukan jiwa wirausaha, digunakan metode market day dan bisnis challange agar murid terbiasa berinteraksi dengan unit, pelaku, dan lingkungan bisnis. Dalam membentuk akhlaqul kariimah, digunakan metode keteladanan. Semua perkataan dan perbuatan guru harus mencontohkan akhlak secara nyata kepada peserta didik.

\section{Kelemahan Sekolah Alam}

Pertama, sekolah alam yang ada saat ini masih terbatas, hanya beberapa sekolah alam yang mempunyai tingkatan sampai jenjang SMP, selebihnya masih pada tingkatan untuk taman kanak-kanak dan SD.

Kedua, faktor biaya masuk ke sekolah alam rata-rata memang bisa dikatakan mahal. Mungkin tidak akan menjadi problematika bagi kalangan menengah keatas untuk menyekolahkan anak mereka, namun tidak demikian bagi kalangan menengah kebawah yang berpenghasilan serba pas-pasan. Sebagai contoh, rata-rata sekolah alam memungut biaya yang harus ditanggung wali murid untuk uang masuk kelompok bermain dan TK misalnya, Rp 1.500.000,00 dan biaya operasional guru Rp 300.000,00 perbulan. Untuk SD dan lanjutan setara SLTP dikenai uang masuk Rp 2.000.000,00 dan iuran masingmasing Rp. 400.000,00 per bulan untuk SDdan Rp 500.000,00 perbulan untuk SLTP.

Ketiga, faktor tempat meskipun secara teori sekolah alam dapat dilakukan di mana saja dengan fasilitas yang paling sederhana sekalipun.Namun pada realitanya sekolah alam membutuhkan tempat yang luas berdasarkan sumber yang dijadikan rujukan, terutama sekali pembelajaran yang membutuhkan tempat untuk praktek, seperti farming dan outbound.

\section{Karakteristik Peserta Didik}

Karakter didefinisikan oleh Ryan dan Bohlin, mengandung tiga unsur pokok, yaitu knowing the good, loving the good, dan doing the good. Hornby dan Parnwell mengemukakan bahwa karakter merupakan kualitas moral dan mental, kekuatan moral, norma, dan reputasi (Majid dan Andayani 2012).

Megawangi pencetus pendidikan karakter di Indonesia telah menyusun 9 pilar karakter mulia yang dijadikan acuan dalam pendidikan karakter di sekolah maupun di luar lingkungan sekolah, yaitu sebagai berikut: cinta Allah dan kebenaran; amanah, disiplin dan mandiri; tanggung jawab; hormat dan santun; kasih sayang, peduli, dan kerja sama; kratif, percaya diri, dan pantang 
menyerah; adil dan berjiwa kepemimpinan; baik dan rendah hati; serta toleran dan cinta damai (Mulyasa 2013).

Berbicara tentang karakter maka erat kaitannya dengan peserta didik. Peserta didik merupakan indiividu yang sedang berkembang memiliki potensi tertentu. Dengan bantuan pendidik, maka potensi yang dimiliki peserta didik dapat dikembangkan secara optimal. Dengan demikian, karakter peserta didik mengandung makna sifat yang ada pada seseorang dan dapat diidentifikasikan sebagai manusia yang sungguh-sungguh dalam mencari ilmu pengetahuan untuk bekal di masa depan baik kehidupan dunia maupun akhirat.

Beberapa prinsip pembentukan karakter peserta didik dikemukakan Nana Prasetyo, sebagai berikut.

1. Faktor bawaan dan lingkungan

Faktor yang memengaruhi karakter dibagi menjadi 2, yaitu bawaan dari dalam diri anak dan pandangan anak terhadap pengetahuan, pengalaman, prinsip-prinsip moral yang diterima, bimbingan, pengarahan, dan interaksi (hubungan) (Fauziah et al. 2015). Seperti dalam hadist Rasulullah Saw.

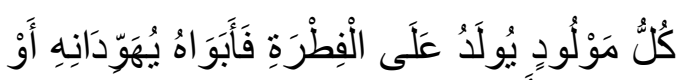

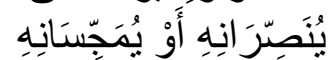

"Setiap anak dilahirkan dalam keadaan fithrah. Kemudian orangtuanyalah yang akan menjadikan anak itu menjadi yahudi, Nasrani atau Majusi..." (HR. Bukhari)

2. Orang tua yang berkarakter menumbuhkan anak yang berkarakter

3. Karakter dapat dibentuk mulai sejak usia dini dan berlangsung seumur hidup

\section{Metode}

\section{Metode Penelitian}

Penelitian ini menggunakan pendekatan kualitatif dengan metode penelitian deskriptif. Penelitian kualitatif (qualitatif research) yang digunakan untuk meneliti pada kondisi objek yang alamiah, peneliti disini berperan sebagai instrumen kunci (Sugiyono 2015).

Metode penelitian menggunakan kualitatif deskriptif, bertujuan untuk menggambarkan situasi atau fenomena, yang dirancang untuk mendapat suatu informasi dalam keadaan sekarang atau apa adanya dengan cara mengumpulan informasi, menggali, mengamati, dan meneliti (Rukaesih et al. 2013).

Sumber data diperoleh dari subyek dalam penelitian yaitu bidang kurikulum, kepala sekolah, dan guru. Dalam menemukan data yang benar tentang manajemen pembelajaran berbasis sekolah alam dalam membentuk karakter peserta didik, peneliti menggunakan teknik pengumpulan data melalui observasi, wawancara, dan dokumentasi. Selanjutnya untuk menganalisis data yang telah dikumpulkan sejak awal sampai akhir peneliti menggunakan reduksi data, penyajian data, dan kesimpulan.

\section{Teknik Pengumpulan Data}

Pengumpulan data merupakan langkah yang paling strategis dalam penelitian karena bertujuan untuk mendapatkan data. Tanpa mengetahui teknik pengumpulan data, maka peneliti tidak akan mendapatkan data yang di tetapkan. Teknik pengumpulan data dapat dilakukan dengan, wawancara, observasi, dokumentasi (Sugiyono 2015). 


\section{Teknik Analisis Data}

Analisis data kualitatif adalah bersifat induktif, yaitu suatu analisis berdasarkan data yang diperoleh, selanjutnya dikembangkan pola hubungan tertentu atau menjadi hipotesis. Berdasarkan hipotesis yang dirumuskan berdasarkan data tersebut, selanjutnya dicarikan data lagi secara berulang-ulang sehingga selanjutnya dapat disimpulkan apakah hipotesis tersebut diterima atau ditolak berdasarkan data yang terkumpul. Bila berdasarkan data yang dapat dikumpulkan secara berulang-ulang dengan teknik triangulasi, ternyata hipotesis diterima, maka hipotesis tersebut berkembang menjadi teori. Adapun langkahlangkah dalam analisis data dalam penelitian ini di antaranya: reduksi data (data reduction), data display (penyajian data), conclution drawing atau verification (kesimpulan).

\section{HASIL DAN PEMBAHASAN}

\section{Hasil}

\section{Pengorganisasian \\ Pembelajaran Berbasis Sekolah Alam}

Dalam hal pengorganisasian pembelajaran di SDIslam Ibnu Hajar Bogor dilaksanakan pada rapat awal tahun pelajaran, dalam rapat tersebut kepala sekolah menanyakan langsung kesiapan dan kesediaan orang yang dipilih dan ditetapkan agar saat mengemban tugas dan tanggungjawab tersebut tidak dalam keadaan terpaksa. Maka dari itu disusunlah struktur organisasinya. Dalam struktur organisasi untuk penentuan wali kelas disebutkan siapa saja guru yang mengajar dan di kelas berapa, dengan uraian penjelasan pekerjaan apa yang akan dilakukan guru atau job description. Selain itu, dalam struktur pengorganisasian menentukan penanggungjawab guru disetiap program kegiatan yang akan dilaksanakan baik itu program hariannya, program semester dan program tahunan, semua penanggung jawab sudah dikelompokkan.

Dikarenakan pembuatan RPP dibuat satu minggu sekali, maka ditentukan pula pembagian tugas untuk membuat RPP pada guru masing-masing level kelas. Dalam 1 level atau 1 tingkatan terdiri dari 3 kelas, maka guru kelas dalam 1 level adalah 6 guru. Dari keenam guru tersebut diberikan penugasan pembuatan RPP yang dilakukan secara bergiliran setiap minggunya.

\section{Pelaksanaan Pembelajaran Berbasis Sekolah Alam}

Terdapat tiga tahapan pelaksanaan pembelajaran di SD Islam Ibnu Hajar Bogor, yaitu sebagai berikut.

Pre-Activities merupakan kegiatan awal pembelajaran. Ketika peserta didik sampai di sekolah yang pertama kali peserta didik lakukan adalah

Spritual Alphazone, kegiatan Spritual Alphazone. Peserta didik dilatih untuk membiasakan shalat Dhuha berjama'ah, dari kelas 1 sampai kelas 4 mereka shalat di ruang kelas dengan dibimbing oleh guru masing-masing kelas tersebut, sedangkan untuk kelas 5 dan 6 shalat Dhuha dilaksanakan di Mushola dan sudah tidak perlu didampingi gurunya. Setelah peserta didik melaksanakan shalat dhuha, mereka berkumpul lalu mereka muroja'ah (mengulang) hafalan surat, hadits, dan do'a.

Guru memberikan STIFIn Alphazone atau pengaktifan mesin kecerdasan setiap peserta didik sebelum dimulainya pembelajaran. Pemberian STIFIn Alphazone di tiap kelasnya berbeda-beda. 
Tabel 1 Kegiatan Harian SDI Ibnu Hajar

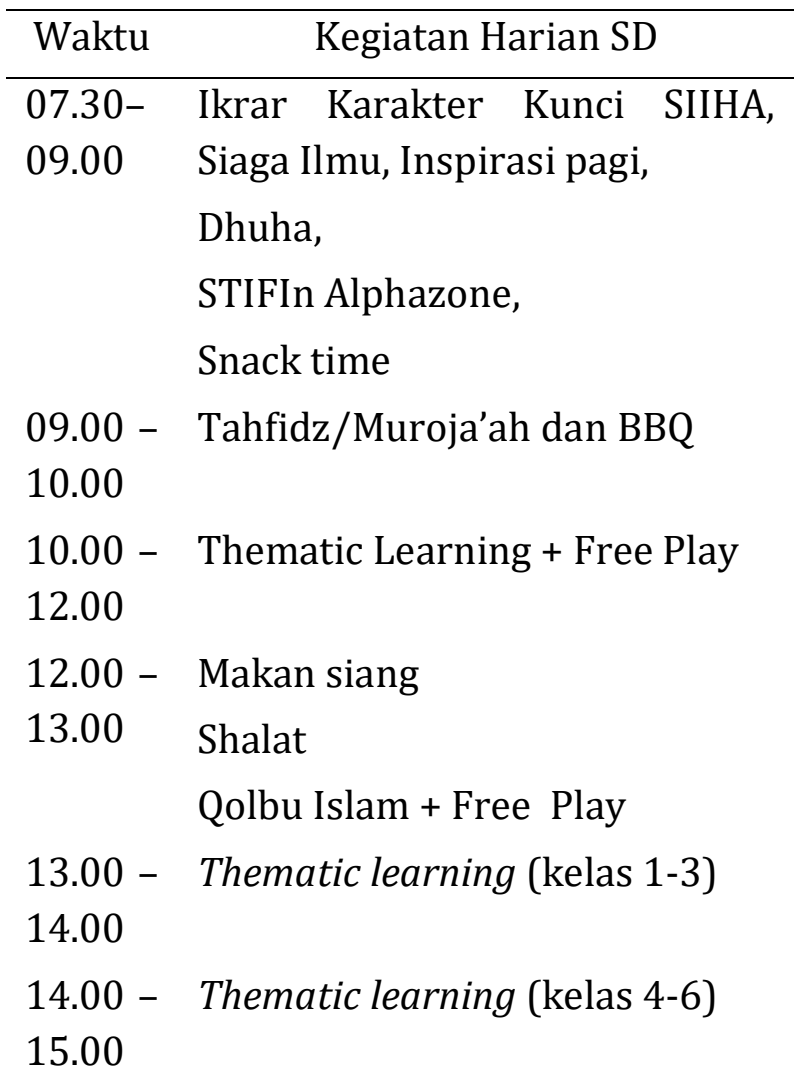

Main Activity. Pada kegiatan inti pembelajaran, guru tidak hanya melakukan pembelajaran di dalam kelas, tetapi juga guru banyak memberikan penyampaian materi di luar kelas. Baik itu di lingkungan sekolah atau lingkungan sekitar sekolah. Pada pembalajaran di dalam kelas guru akan melakukan scene setting yaitu peserta didik harus sudah siap dengan peralatannya masing-masing dan duduk rapi di atas karpet. Tujuan guru melaksanakan kegiatan di luar kelas ini yaitu, melatih anak agar berani bertanya, dan anak mendapatkan informasi dari sumber langsung.

Post Activity. Di setiap akhir pembelajaran guru mengevaluasian pembelajaran yang telah disampaikan. Guru memberikan worksheet semacam lembar jawaban, untuk diisi oleh anak. Worksheet yang diberikan guru dalam bentuk soal, pengamatan, dan project kelas. Adapun rutinitas yang dilakukan peserta didik setiap harinya seperti Tabel 1.

\section{Pengawasan Pembelajaran Berbasis Sekolah Alam}

Dari hasil wawancara dengan kepala sekolah dapat diketahui bahwa bentuk pengawasan pembelajaran di SDIslam Ibnu Hajar Bogor dalam mengelola sekolah alam yang efektif dengan bentuk pengawasan melekat.

Mekanisme pelaksanaan pengawasan melekat yang diterapkan adalah (1) pemeriksaan secara rutin setiap pekan terhadap RPP dan administrasi kelas yang dibuat oleh masing-masing guru, (2) kepala sekolah melakukan pemeriksaan langsung ke kelas saat guru-guru sedang mengajar tanpa ada pemberitahuan, (3) melakukan rapat kerja guru setiap pekan dengan tahap berjenjang yang dilakukan oleh kepala sekolah untuk pelaporan perkembangan program pembelajaran yang sudah berlangsung.

Pada pengawasan program pembelajaran yang dilakukan kepala sekolah yaitu, mengontrol kegiatan peserta didik yang sedang berjalan dan yang sudah berlangsung seperti; perkembangan UMMI, perkembangan pencapaian hafalan ayat, hadits dan do'a, data peserta ekstrakulikuler, rencana pembiayaan untuk KE (Kunjungan edukatif), dan home visit. Pengawasan program ini dilakukan ketika rapat guru setiap pekannya yang bertujuan untuk mengetahui permasalahan-permasalahan yang dihadapi oleh para guru dalam satu pekan agar bisa dicarikan solusinya secara musyawarah.

\section{Evaluasi atau Penilaian Pembelajaran Berbasis Sekolah Alam}

Dari hasil wawancara peneliti dengan kepala sekolah dan guru, sistem penilaian pembelajaran di SD Islam Ibnu Hajar terdiri 
dari 3 aspek, yaitu: penilaian angka, penilaian perkembangan anak, dan penilaian potensi genetik. Penilaian angka diambil dari penilaian harian (worksheet), Studi with Parent (SWP) yang berisikan latihan-latihan soal selama 1 bulan pembelajaran untuk dikerjakan oleh peserta didik dengan dibimbing orang tua. penilaian Ujian Tengah Semester, dan penilaian Ujian Akhir Semester.

Pembeda antara SD Islam Ibnu Hajar dengan sekolah alam lainnya dan sekolah umum/sekolah konvensional yaitu masingmasing dari aspek penilaian mempunyai raport tersendiri. SDIslam Ibnu Hajar memiliki 3 raport.Yang pertama, Raport STIFIn merupakan raport deskripsi pencapaian potensi anak. Yang kedua, Raport perkembangan anak merupakan deskripsi perkembangan karakter anak. Dan yang ketiga, Raport angka merupakan raport nilai UTS, atau UAS anak.

\section{Proses Membentuk Karakter Peserta Didik}

Dari hasil penelitian mengenai proses Pembentukan karakter peserta didik yang dikembangkan di SDIslam Ibnu Hajar, guru menjadi tauladan dan contoh bagi peserta didiknya, menerapkan nilai-nilai di setiap aktivitas peserta didik di lingkungan sekolah, mengkaitkan pembelajaran pada pembangunan karakter anak dan memang di SDIslam Ibnu Hajar ini mempunyai kurikulum tersendiri yang berkaitan dengan karakter yaitu, Ma'rifatul Insan yang memfokuskan kepada Pembentukan nilainilai, jiwa kepemimpinan dan jiwa kewirausahaan.

Proses Pembentukan nilai-nilai dengan menerapkan 7 kata ajaib yaitu: Assalamu'alaikum, Bismillah, Alhamdulillah, Maaf, Permisi, Tolong, dan Terimakasih.
Pembentukan jiwa kepemimpinan mengadakan program outbond, tujuan utama program tersebut memang untuk melatih jiwa kepemimpinan peserta didik. Selain outbond, upaya guru untuk melatih jiwa kepemimpinan anak yaitu dengan cara penerapan menjadi ketua kelas, menjadi ketua kelompok, imam shalat khusus ikhwan, memimpin muroja'ah dan lain sebagainya. Hal-hal seperti itu jika dilakukan terus-menerus dan berulang-ulang secara tidak langsung akan membentuk jiwa kepemimpinan anak.

Pembentukan jiwa kewirausahaan dengan diadakannya program bisnis challange dan market day bertujuan agar anak sudah mengenal wirausaha sejak dini sehingga anak dapat mengelola modal dengan baik dan membuat suatu produk yang mempunyai harga jual.

\section{Pembahasan}

\section{Profil SD Islam Ibnu Hajar Bogor}

Sekolah Islam Ibnu Hajar Bogor adalah sebuah lembaga pendidikan yang berada dalam naungan Yayasan Demi Masa Kehalutuju. Yayasan Demi Masa Kehalutuju memiliki dua lembaga yaitu SD Islam Ibnu Hajar Bogor dan SMP Islam Ibnu Hajar Bogor. Sekolah Islam Ibnu Hajar (SIIHA) merupakan nama dari salah seorang filsuf muslim yang terkenal yang bernama "Ibnu Hajar Al Atsqolani".

Pada awalnya sekolah masih berada pada level TK Islam bertempat di Masjid Raya Bogor, tetapi karena permintaan orang tua sangat tinggi maka akhirnya dibuatlah sebuah lembaga sekolah dasar yang bernama SD Islam di tahun 2011.

SD Islam Ibnu Hajar dipindah lokasikan pada tahun 2014 karena SD Islam Ibnu Hajar butuh pengembangan. Maka, sistem pengelolaannya harus secara mandiri di 
lokasi baru yaitu di Jl. Raya Katulampa, Desa Parung Banteng Kel. Katulampa Kec. Bogor Timur Kota Bogor. Kemudian untuk TK-nya dikembalikan kepada pengelola Masjid Raya Bogor.

\section{Perencanaan Pembelajaran Berbasis Sekolah Alam}

Berdasarkan hasil wawancara, observasi, dan studi dokumentasi di SDIslam Ibnu Hajar Bogor berkaitan dengan perencanaan pembelajaran berbasis sekolah alam dalam membentuk karakter peserta didik.

Proses perencanaan pembelajaran diawali dengan penyelenggaraan rapat kerja tahunan yang membahas tentang Tema besar perencanaan kegiatan dalam 1 tahun kedepan (action plan). Setelah rencana kegiatan tersebut di ACC oleh manajer pendidikan dan direktur program, barulah di adakan rapat kerja guru di setiap awal semester (RKS).

Rapat kerja semester rutin dilaksanakan setiap satu semester sekali yang diadakan oleh Manajer Pendidikan bersama dengan Kepala sekolah dan Guru-guru SDIslam Ibnu Hajar Bogor sesungguhnya, yang akan membahas mengenai standar proses pembelajaran dan pembuatan kalender pendidikan sekolah. Kalender pendidikan berfungsi sebagai panduan semua guru dalam perencanaan program pembelajaran. Rapat kerja guru di semester pertama, membahas kelanjutan dari tema besar yang dijadikan acuan bagi guru-guru dalam membuat perencanaan pembelajaran (Lesson Plan), rapat kerja guru di semester dua hanya melanjutkan tema yang sudah ditentukan sebelumnya. Rapat kerja semester ini dilaksanakan dalam waktu 1 minggu berturut-turut sebelum memasuki kegiatan pembelajaran semester.

Langkah-langkah penyusunan Lesson Plan diantaranya, Spider Tema dan Sub Tema,
Spide Aliran Ilmu, Spider KD, Spider Activity, Kriteria Ketuntasan Minimal (KKM), Silabus, dan Rencana Pelaksanaan Pembelajaran. Komponen-komponen perencanaan pembelajaran tersebut mengacu pada kurikulum khas yang diterapkan, yaitu ma'rifatullah, ma'rifatul insan, dan ma'rifatul alam. Yang menjadi fokus perencanaan pembelajaran di SDIslam Ibnu Hajar Bogor adalah sebagai penempaan minat bakat anak sesuai potensi genetik peserta didik dan akhlakul kariimah.

Program pembelajaran pun disusun pada saat perencanaan. Program pembelajaran disesuaikan dengan kurikulum SDIslam Ibnu Hajar yang memang mempunyai beberapa program unggulan. Urutan program dan tujuan untuk setiap level kelasnya pun berbeda-beda yaitu sebagai berikut.

1. Program Harian berlaku untuk semua level kelas: Program Hafalan Al-Qur'an, Hadist, dan Do'a sehari-hari, Program GARIS (Gerakan Rapikan Sandal), Program Zero Weis (Non Sampah Pelastik), dan Outing.

2. Program Semester: Home Visit/kunjungan ke rumah, Outbond, Aqua play/Berenang, Kunjungan Edukatif (KE), dan Bisnis Challange.

3. Program Tahunan: HUT RI, Qurban di sekolah, Market Day, Family Gathering, Fijar (Festival Ibnu Hajar), dan Penyaluran infak.

Temuan penelitian di atas menunjukkan bahwa, secara umum SDIslam Ibnu Hajar Bogor telah melakukan fungsi perencanaan pembelajaran yang mendekati apa yang seharusnya ada dalam sebuah perencanaan pembelajaran berbasis sekolah alam. Perencanaan yang dilakukan mengaitkan antara pembelajaran dengan karakter peserta didik yang akan dibentuk. 


\section{KESIMPULAN DAN IMPLIKASI}

\section{Kesimpulan}

Berdasarkan hasil penelitian yang telah dilakukan di SD Islam Ibnu Hajar Bogor dapat diambil simpulan bahwa:

1. Perencanaan pembelajaran berbasis sekolah alam harus berdasarkan berdasarkan 3 muatan kurikulum, yaitu: ma'rifatullah, ma'rifatul insan, dan ma'rifatul alam. Dari mulai guru membuat Lesson Plan. Meliputi, spider tema dan sub- tema, spider aliran ilmu, spider KD, spider aktivitas, KKM, Silabus, dan RPP. Guru membuat perencanaan program. Meliputi, program harian, program semester, dan program tahunan.

2. Pengorganisasian pembelajaran berbasis sekolah alam dilaksanakan pada rapat awal tahun pelajaran, dalam rapat tersebut kepala sekolah menentukan guru kelas, pembagian penanggujawab setiap program pembelajaran, dan pembagian tugas pembuatan RPP pada setiap level kelas.

3. Pelaksanaan pembelajaran berbasis sekolah alam guru melakukan proses pembelajaran dengan sangat sistematis. Kegiatan pembelajaran menggunakan pendekatan saintifik, metode pembelajaran tematik yang mengintegrasikan kompetensi dasar dengan beberapa mata pelajaran, dan pelaksanaan pembelajarannya dengan menggunakan strategi STIFIn learning yaitu, kegiatan spritual alphazone, STIFIn alphazone dan thematic learning.

4. Mekanisme pengawasan pembelajaran berbasis sekolah alam yang dilakukan oleh kepala sekolah adalah pemeriksaan RPP setiap pekan, pengamatan proses pembelajaran, pengawasan program yang sedang berjalan dan yang sudah berlangsung.

5. Penilaian pembelajaranyang dilakukan terdiri dari 3 aspek, penilaian potensi anak dengan raport STIFIn, penilaian perkembangan anak dengan raport perkembangan, dan penilaian pengetahuan dengan raport angka.

6. Proses Pembentukan karakter peserta didik yang dikembangkan yaitu lebih menekankan pada pembentukan akhlak dengan 7 kata ajaib, pembentukan jiwa kepemimpinan dengan outbond, imam shalat, menjadi ketua kelas, memimpin muroja'ah. Pembentukan jiwa kewirausahaan dengan bisnis challenge dan market day.

\section{Implikasi}

Dari hasil penelitian ini dapat dikembangkan penelitian yang serupa tentang manajemen pembelajaran berbasis sekolah alam, serta dapat membentuk karaktaristik peserta didik dalam menumbuhkan jiwa manajerial serta dapat mencapai lulusan terdidik yang mandiri dan berkarakter. Maka akan berimplikasi seandainya manajemen berbasis sekolah dengan stakeholder lainya mulai dari kepala sekolah, tenaga pendidik dan peserta didik harus saling bekerjasama dengan baik agar tujuan pendidikan dapatterwujud sesuai dengan apa yang diharapkan.

\section{DAFTAR PUSTAKA}

Arikunto S. 2002. Dasar-dasar evaluasi pendidikan. Bumi Aksara, Jakarta.

Bafadal I. 2012. Manajemen peningkatan mutu SD. Bumi Aksara, Jakarta.

Hamalik. 2001. Evaluasi pembelajaran. Bumi Aksara, Jakarta. 
Kesuma D et al. 2013. Pendidikan karakter: kajian teori dan praktik di sekolah. Remaja Rosdakarya, Bandung.

Majid A. 2012. Belajar dan pembelajaran. Remaja Rosdakarya, Bandung.

Majid A. 2013. Strategi pembelajaran. Remaja Rosdakarya, Bandung.

Yamin M. 2013. Desain Pembelajaran berbasis tingkat satuan pendidikan. Referensi, Jakarta.

Maryati. 2007. Sekolah Alam. Alternatif pendidikan sains yang membebaskan dan menyenangkan. Jurnal Prosiding Seminar Nasional Penelitian. Yogyakarta, 25 Agustus 2007, ISSN 978-979-99314-2-9.

Muhaimin et al. 2011. Manajemen pendidikan aplikasinya dalam penyusunan rencana pengembangan sekolah/madrasah. Kencana, Jakarta.

Rukaesih MA et al. 2015. Metodologi penelitian pendidikan. Raja Grafindo Persada, Jakarta.

Sagala S. 2013. Konsep dan makna pembelajaran. Alfabeta, Bandung.

Sugiyono. 2015. Metode penelitian pendidikan: pendekatan kuantitatif, kualitatif dan R\&D. Alfabeta, Bandung.

Undang-Undang Republik Indonesia No 20 tahun 2003 tentang Sistem Pendidikan Nasional.

Yamin M. 2013. Paradigma baru pembelajaran. Referensi, Jakarta. 